\title{
Happiness Value Inside Traditional Ceremony of Begalan: Research on Communication Activities Ritual Wedding
}

\author{
Alva Kurniawan ${ }^{1}$, Sahid Widodo ${ }^{2}$, Kundharu Saddhono ${ }^{3}$ \\ ${ }^{1}$ Student Sebelas Maret University, Surakarta-Indonesia \\ ${ }^{2,3}$ Graduate Program of Sebelas Maret University, Surakarta-Indonesia
}

alvakurniawan3@gmail.com

\begin{abstract}
The purpose of this study was to describe: (1) the form of Begalan traditional ceremony, (2) the meaning contained in brenangkepang, (3) how the communicative situation, communicative events, and how the communicative action. This research is descriptive qualitative. The data collection techniques in this study are observation, interview, and reviewing documents and archives. The object of this study is a communication activities traditional ceremony of Begalan Banyumasan. The data analysis technique in this research is qualitative descriptive analysis and interactive. Begalan Banyumasan traditional ceremony is a form of ritual to get rid of negative things. From the order of performance time, speech, and tools brought in Begalan have meaning and religious value. Beside that, Begalan many contain educational values for brides and people who see.
\end{abstract}

Keywords: Activity of Communication; Traditional Ceremony; Begalan.

\section{INTRODUCTION}

Banyumas is located in along Serayu river area. Banyumas regency is a part of central java area which is laid between $108^{\circ} 39^{\prime} 17^{\prime \prime}-109^{\circ} 27^{\prime} 15^{\prime \prime}$ longitude east and $7^{\circ} 15^{\prime} 05^{\prime \prime}-7^{\circ} 37^{\prime} 10^{\prime \prime}$ southern latitude. This regency is abuted on some other areas like Tegal and Pemalang regency in the north, Brebes and Cilacap regency in the west, and Purbalingga, Banjarnegara, and Kebumen regency in the south [1].

Geographically, Banyumas area is included in southern Centra Java Province area which is usually called "Red area". This term has meaning that the southern central Java area especially Banyumas, is a community that strong of Javanese culture. The culture is adopted from HinduBudha kingdom that have animisme and dinamisme mithology. 
That culture are still exist and develop this day. Some of them are Lengger, Aksimudha, Angguk, Aplang, Baritan, Bongkel, Buncis, Calung, Ebeg, Begalan, and Kenthongan. In the beginning, they have function as religion ceremony, gratitude of god ceremony, although ruwatan ceremony or disaster rejection ceremony. But, nowadays that cultures are developed through developing ages [2].

Indonesian culture is very diverse and each area is different. In Java itself there are many cultures that span from Central Java, East Java, and Yogyakarta [3]. Banyumas has so many cultures, one of them that has its own specific characteristic is begalan. Begalan is a tradition that is held in wedding ceremony, in ex karesidenan Banyumas area, this culture is started by the groom and his whole family enter the bride's house. This tradition is done if the groom is the oldest son of a family [4].

In the development, Begalan experiences some changes. This is absolutely because of technology and information development. In socialisation process now, someone can take down himself for the sake of society admission. Partied to being rejected and unaccepted all at once is a threat for some individues. The function consideration is not counted from symbol and certain culture status, until popping out waht we called trend [5].

Culture changes is the beginning of transformation. The culture changes is a changes process of that culture itself, through so many ways like acculturation, inculturation, or syncretism. Whereas culture transformation is a culture which is a new form from the result or process of the changes [6]. There are some factors that influence culture changes [7]. They are (1) contact with other culture, (2) advance education system, (3) respect attitude of someone's work and passion to achiev something, (4) tolerance toward diverge attitude, (5) an open society system , (6) dissatisfaction of something, (7) future orientation, (8) living standard increase point.

Implementation Begalan can not be separated from communication activities. Communication and culture have reciprocal relationships. Culture becomes a communication behavior, and communication contributes to maintaining, developing, and bequeathing culture. Communication activity means identifying events and or communication processes. The communication activities consist of three units, namely communicative situations, communicative events, and communicative actions [8].

\section{RESEARCH METHOD}

The study about the equipment of the brenangkepang in Begalan Banyumasan traditional ceremonies carried out in Banyumas. This study was a qualitative research. The type of the study was qualitative descriptive. That is by performing a research of the objects finding and interpret the relationship of the various elements in it. The data collection techniques in this study were observation, interview, and reviewing documents and archives (content analysis). The data analysis technique in this research is qualitative descriptive analysis and interactive, the data analysis focuses on the meaning, descriptions, and placement of data on the each context [9].

\section{RESULTS AND DISCUSSIONS}

The ancient brenang kepang contained twelve kinds of kitchen equipment that made from natural materials. The equipment of ancient brenang kepang were ian, ilir, embatan, kukusan, 
cirimuthu, cething, centhong, tampah, siwur, irus, kendhilpratala, kekeb, sorok, sapulidi, dan padi. The form of brenang kepang developed in the Banyumas society was mostly using the ancient brenangkepang. The kitchen equipment used in modern or contemporary brenangkepang was not made from the natural materials and some of the equipment are being replaced without reduced its function. The modern or contemporary brenangkepang was the form of brenangkepang that consist of kitchen equipment but the material was not from the nature, like bamboo. Some of the equipment was replaced with the modern one, such as: Cething was replaced with magic jar, siwurwas replaced withplastic water dipper, sorok replaced with stainless sorok, and another kitchen equipment made of plastic. Thus, not all of the equipment carried in modern brenangkepang is made of natural materials [10].

The reason of using the modern kitchen equipment were: (1) the house owner thought that it is more efficient, it is easy to get those things; (2) the householder thought that the modern kitchen equipment can replaced the old kitchen equipment because it has the same function; (3) Some people who held Begalan Banyumasan was having difficulties to find the kitchen equipment in ancient brenangkepang. The form of brenangkepang usually provided and assembled by the BegalanBanyumasan performances. So, they can know about the equipment that being used and arranged to explain it to the audience.

There were some of the house owners that held Begalan Banyumasan ceremony provided ancient brenangkepang. It was easier for the performances of Begalan Banyumasan because they did not need to carry and arrange the kitchen equipment used in brenangkepang. The performances of Begalan Banyumasan just recited the meaning of all the symbols in the form of kitchen equipment and gave some advices on married life provision [4].The second form of brenangkepang is modern or contemporary brenangkepang. The forms has been modified and developed in some of the kitchen equipmnet used. The modern or contemporary brenangkepang was the form of brenangkepang that consist of kitchen equipment but the material was not from the nature.

Begalan Banyumasan traditional ceremony was one of ritual to rid of the negative things from the brides (sukerta). This has been done by explaining the meanings conveyed through the symbolization of brenangkepang equipment. Thus were appropriate with the results of study by Sunarto titled Leather Puppet in Javanese Ritual Ceremony. The results showed that the shadow puppet show can be used as a tool of ritual to get rid of negative things (larungsukerta) for someone.

Along with the development of Islamic culture in Banyumas, the use of mantra and sesaji start to be left. In the past, people can not be separated from magic things so they still use mantra and sesaji but this day they only need to be prayed. One of the ritual that must be did before Begalan is sesaji giving. Sesaji that they give are, Tumbeng sewu, is a small tumpeng that amount to 1000. Panggang Emas or roasted Fish. Kembang telon or three kinds of flowers. Wedhang pitu is seven kinds of beverages. Wedhang Jembawuk, etc [2].

The changes og Begalan is caused by some factors. First, modern wedding. As we know that this day people prefer use western culture in theit wedding day, they do not use javanese culture anymore. Example, begalan as the opening of a wedding ceremony is replaced by piano playing, or two girls bring a flower bouquet. Second, islam influence, religion has influence in culture as in Hasse's research [11]. Begalan have purpose a ruwatan or disaster admission. That thing are not suitable with islamic rules. Because of that, the implementation is changed as an entertainment need only. Mantra and sesaji are not used anymore. The ritual is started by praying 
to God. And sometimes they add tausiyah in the ceremony. Third, the open society. People in Banyumas has open minded, and honest characters [12]. This character cuased the other culture can be accepted easily there. In addition, the society can accept the changes of tools from bamboo to plastic that easy to use.

The communicative situation in the Begalan tradition is sacred, but full of excitement. The picture of the situation is sacred because it contains the element of rejecting reinforcements (driving away bad things). Happy because begal and legal conversations contain humor, which makes the audience laugh. The event took place competitively the day before the celebration began so as to make people watch a lot.

Communicative events are events that describe the process of tradition from the beginning to the end. Everything is done when the groom comes. A group of grooms were intercepted in front of the celebration. Then there was a robbery followed by an explanation of the meaning of the tools carried by the groom. Every tool that is brought is a symbol of value or advice for the bride.

Communicative action is a single interaction function such as statements, requests, orders, or non-verbal behavior [13]. Communicative action in the form consists of forms of verbal and non verbal communication. In Begalan the forms of verbal and non verbal communication are carried out verbally and symbolically. Symbolic interaction occurs when describing forms of communication with God so that brides are kept away from danger, but even then symbolic interactions are carried out with brides and spectators at that time. The symbols in the robbed tools contain messages for both the bride and the people watching at the time.

\section{CONCLUSION}

The first Begalan culture changes is the tools change. In the past, Begalan used simple tools from bamboo, then, use plastic tools or materials that can be found easily now. Second, there are no mantra and sesaji. Third, function change from ruwatan ritual to entertaiment medium. That things can happen because of some factors like modern wedding, islamic influence, and society open characteristic.

Technology and information development give so many influences to Begalan culture. With an advance technology, many kinds of information and foreign cultures can be accepted easily. Cultural changes in begalan can't be avoided. The changes in Begalan is an effort to keep the existence. If it can't follow the modern development, Begalan culture will extinct. The efforts to keep Begalan is the society and government duty to keep the culture existence.

The communicative situation in the Begalan tradition is carried out when the bridegroom comes. A group of grooms were intercepted. Then there was a robbery followed by an explanation of the meaning of the tools carried by the groom. Communicative action in the form consists of forms of verbal and non verbal communication.

\section{REFERENCES}

[1] N. Suwito, Islam dalam Tradisi Begalan. Purwokerto: Stain Press, 2008.

[2] A. Setiawan, "Alih Fungsi Tradisi Begalan dalam Adat Perkawinan Banyumas (Studi tentang Eksistensi Tradisi Begalan dalam Masyarakat Banyumas)," J. Prodi Pendidik. Bhs. dan Sastra Jawa Univ. Muhammadiyah Purworejo, vol. 6, no. 4, pp. 9-17, 15AD. 
[3] K. Saddhono, "Cultural and social change of foreign students in Indonesia: The influence of Javanese Culture in Teaching Indonesian to Speakers of Other Languages (TISOL)," IOP Conf. Ser. Earth Environ. Sci., vol. 126, p. 12091, 2018.

[4] B. Herusatoto, Banyumas: Sejarah, Budaya, Bahasa, dan Watak. Yogyakarta: LkiS Pelangi Aksara, 2008.

[5] Susminingsih, "Konsumsi; antara Agama, Ritual, dan Transformasi Budaya," J. IEconomic, vol. 3, no. 1, pp. 115-128, 2017.

[6] B. Sisworo, "Transformasi Budaya dalam Kesenian Lengger Temanggung Perkotaan," J. Urban Soc. Art, vol. 12, no. 2, pp. 65-76, 2012.

[7] R. Tjejep, Pendekatan Sistem Sosial Budaya dalam Pendidikan. Semarang: UNNES Press, 1994.

[8] M. Sari, "Aktifitas Komunikasi Upacara Adat Penen tebu," J. E-Prceeding maganement, vol. 3, no. 3, 6AD.

[9] H. Sutopo, Metodologi Penelitian Kualitatif. Surakarta: Universitas Sebeleas Maret Press, 2016.

[10] K. Saddhono and A. Kurniawan, "Islamic Religious Value in Traditional Ceremony of Begalan Banyumasan as Educational Character for Student at Senior High Schools in Central Java," Umr. Int. J. Islam. Civilizational Stud., vol. 4, no. 1, pp. 71-77, 2017.

[11] J. Hasse, "Dinamika Hubungan Islam dan Agama Lokal di Indonesia: Pengalaman Towani Tolotang di Sulawesi Selatan," Wawasan J. Ilm. Agama dan Sos. Budaya, vol. 1, no. 2, pp. 179-186, Aug. 2016.

[12] R. Widyaningsih, "Bahasa Ngapak dan Mentalitas Orang Banyumas: Tinjauan dari Perspektif Filsafat Bahasa Hans-Georg Gadamer," J. Ultim. Hum., vol. 2, no. 3, pp. 186-200, 2015.

[13] E. Kuswarno, Fenomenologi. Bandung: Widya Padjajaran, 2009. 